\title{
AKUNTABILITAS PENGELOAAN ALOKASI DANA DESA (ADD) TAHUN 2017 DI KABUPATEN BREBES
}

\author{
Andri Widianto \\ D3 Akuntansi Politeknik Harapan Bersama \\ email: andriwidi29@gmail.com \\ Erni Unggul Sedya Utami \\ D3 Akuntansi Politeknik Harapan Bersama \\ email: eunggulsu@gmail.com \\ Ririh Sri Harjanti \\ D3 Akuntansi Politeknik Harapan Bersama \\ email:Ririh sri@yahoo.co.id
}

\begin{abstract}
The granting of Village Fund Allocation is intended to support Village Government programs and activities in the fields of Government, development and empowerment. This study provides an overview of the accountability of the village fund allocation management system in the area of Brebes. Data Collection Technique conducted in this research is Interview. Data analysis uses the thinking of Miles and Huberman (2014) in (Kholmi, 2016) namely interactive model data analysis. The results of this study indicate that the stages of Planning, Implementation, Accountability and Supervision are in accordance with the Regulations
\end{abstract}

Keywords:Accountability, Village Fund Allocation

\section{PENDAHULUAN}

Seiring dengan ditetapkannya UndangUndang Nomor 32 Tahun 2004 tentang Pemerintahan Daerah maka Penyelenggaraan pemerintahan di daerah khususnya kabupaten/kota dilaksanakan menurut asas otonomi dan tugas pembantuan dengan prinsip otonomi seluas-luasnya dalam sistem dan prinsip Negara Kesatuan Republik Indonesia.
Dalam perkembangan Otonomi Daerah, Pemerintah Pusat semakin memperhatikan dan menekankan pembangunan masyarakat desa melalui otonomi pemerintahan desa. Penyelenggaraan pemerintahan dan pembangunan desa harus mampu mengakomodasi asprasi masyarakat untuk turut bertanggung jawab terhadap perkembangan kehidupan bersama sebagai warga desa (Muslimin, 2012) 
Sebagai bentuk kesungguhan Pemerintah Pusat dan Pemerintah Daerah sesuai dengan Ketentuan dalam pasal 24 ayat 5 Peraturan Daerah Kabupaten Brebes Nomor 4 Tahun 2015 tentang Keuangan Desa bahwa Pemerintah Daerah mengalokasikan dalam Anggaran Pendapatan dan Belanja Daerah Kabupaten Alokasi Dana Desa (ADD) Setiap Tahun Anggaran. Pemberian Alokasi Dana Desa dimaksudkan guna mendukung program dan kegiatan Pemerintahan Desa dalam bidang Penyelenggaran pemerintahan, pembangunan, pembinaan kemasyarakatan dan pemberdayaan masyarakat

Penyusunan APBDes dan adanya Alokasi Dana Desa . sesuai dengan rencana penggunaan Dana berdasarkan Musyawarah Desa. merupakan bentuk desentralisasi untuk mendorong good governance. Pemerintahan yang baik dan memperhatikan prinsip akuntabilitas dilakukan pada level pemerintahan desa sebagai konsekuensi otonomi desa. Akuntabilitas Publik merupakan kewajiban pihak pemegang amanah (agent) untuk memberikan pertanggungjwaban, menyajikan, melaporkan dan mengungkapkan segala bentuk aktivitas dan kegiatan yang menjadi tanggungjawabnya kepada pemberi amanah (principal) yang memiliki hak dan kewenangan untuk meminta pertanggungjawaban tersebut (Mardiasmo, 2009). Berdasarkan uraian diatas maka penulis tertarik mengambil penelitian dengan judul “ Akuntabilitas Pengelolaan Alokasi Dana Desa Tahun 2017 di Kabupaten Brebes.

\section{METODE PENELITIAN}

Penelitian ini memberikan gambaran kepada para pembaca tentang akuntabilitas sistem pengelolaan alokasi dana desa di wilayah Kabupaten Brebes. Adapun informan dalam penelitian ini adalah informan yang terlibat langsung, memahami dan dapat memberikan informasi tentang Alokasi Dana Desa yaitu Kepala Desa, Sekretaris Desa, Bendahara, Staf Pemerintahan dan Unsur dari Setda Pemerintahan Desa Kabupaten Brebes serta Staf Pemerintahan Desa Di masingmasing Kecamatan di wilayah Kabupaten Brebes. Serta Teknik Pengumpulan Data yang dilakukan dalam penelitian ini adalah Wawancara. Analisis Data menggunakan pemikiran Miles dan Huberman (2014) dalam (Kholmi, 2016) yaitu analisis data model interaktif yang terdiri dari empat kegiatan secara simultan yang terdiri dari pengumpulan data, reduksi data, penyajian data, dan penarikan kesimpulan/ verivikasi. 


\section{HASIL DAN PEMBAHASAN}

a) Gambaran Umum

Objek penelitian dalam penelitian ini merupakan desa di kabupaten brebes, hal ini diperlukan untuk memberikan pendalaman mengenai permasalahan yang akan diteliti lebih lanjut khususnya terkait dengan Alokasi Dana Desa (ADD) Tahun 2017 di Kabupaten Brebes. Berikut ini peneliti sajikan gambaran mengenai wilayah Kabupaten Brebes dan Kondisi Geogerafisnya.

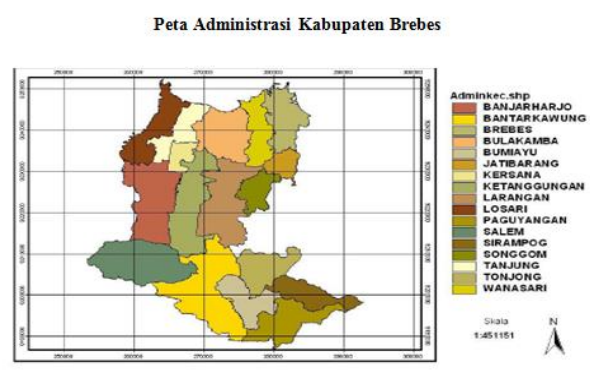

Sumber: Brebes Dalam Data (2016)

Secara Geografis Kabupaten Brebes terletak diantara $6^{0} 44^{\prime} 56,5^{\prime}-7^{0} 20^{\prime} 51,48^{\prime \prime}$ Lintang Selatan dan $108^{0}$ 4137,7”$109^{0} 11$ '28,92” Bujur Timur. Luas Wilayah Kabupaten Brebes 166,296 km2 dan merupakan wilayah terluas setelah kabupaten cilacap yang terdiri dari 17 kecamatan dan 292 Desa. Adapun batas wilayah kabupaten brebes adalah sebagai berikut: Sebelah Utara: Laut Jawa ; Sebelah Timur Kota dan Kabupaten Tegal ; Sebelah Selatan Kabupaten Banyumas dan Cilacap dan Sebelah Barat : Kabupaten Cirebon dan Kuningan di Provinsi Jawa Barat.

b) Alokasi Dana Desa

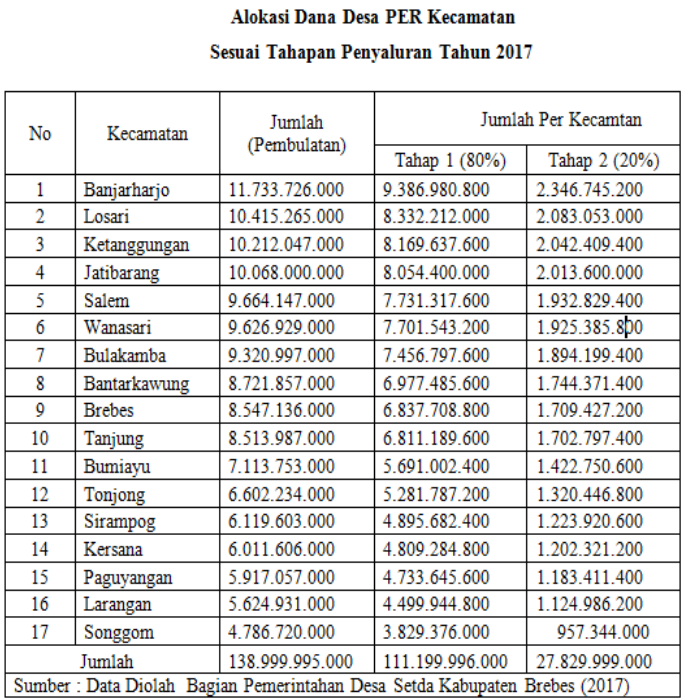

Berdasarkan tabel diatas menunjukan bahwa Alokasi Dana Desa tertinggi yaitu Kecamatan Banjarharjo sebesar Rp 11.733.726.000 sedangkan untuk Alokasi Dana Desa Terendah yaitu Kecamatan Songgom yaitu $\mathrm{Rp}$ 4.786.720.000 dan Kecamatan Brebes menempati posisi tengah-tengah Alokasi Dana Desa yaitu 8.547.136.000

c) Akuntabilitas Dana Desa 
Akuntabilitas sistem pengelolaan ADD dimaksudkan sebagai upaya untuk mewujudkan tata kelola pemerintahan yang baik (good governance). Sebagaimana dikemukakan oleh Haryanto dalam (Arifiyanto, 2014) bahwa prinsip atau kaidah-kaidah good governance adalah adalah partisipasi, transparansi dan pertanggungjawaban dalam pelaksanaan pemerintahan dan pembangunan. Akuntabilitas adalah pertanggungjawaban publik yang berarti bahwa proses penganggaran mulai dari perencanaan, penyusunan, dan pelaksanaan harus benarbenar dapat dilaporkan dan dipertanggungjawabkan kepada masyarakat. Masyarakat tidak hanya memiliki hak untuk mengetahui anggaran tersebut akan tetapi juga berhak menuntut pertanggungjawaban atas rencana atau pelaksanaan anggaran tersebut Mardiasmo (Mardiasmo, 2009)

Alokasi Dana Desa merupakan dana yang dialokasikan oleh pemerintah Kabupaten kepada Desa yang bersumber dari dana perimbangan pusat dan daerah yang diterima kabupaten yang penggunaannya $30 \%$ untuk belanja aparatur dan operasional $70 \%$ untuk belanja publik dan pemberdayaan masyarakat
Pemerintah Daerah mengalokasikan dalam Anggaran Pendapatan dan Belanja Daerah (APBD) Kabupaten Alokasi Dana Desa (ADD) setiap tahun anggaran, yang besarannya paling sedikit 10\% (sepuluh persen) dari dana perimbangan yang diterima Kabupaten Brebes dalam APBD setelah dikurangi dana alokasi khusus. Adapun beberapa pertimbangan dalam mengalokasikan Alokasi Dana Desa (ADD) di kabupaten Brebes adalah seperti: Komponen ADD Reguler, Komponen iuran BPJS Kesehatan dan SILTAP sebagaimana diatur dalam Peraturan Bupati Brebes Nomor 100 Tahun 2016 tentang Alokasi Dana Desa.

Pengelolaan keuangan Alokasi Dana Desa (ADD) merupakan bagian yang tidak terpisahkan dari pengelolaan keuangan desa berdasarkan pada peraturan desa tentang APBDes tahun berkenaan dan disesuaikan dengan perencanaan desa yang ditetapkan dalam peraturan desa tentang RPJMDesa dan RKPDesa tahun berkenaan. Oleh karena itu dalam pengelolaan keuangan desa perlu direncanakan, dilaksanakan dan dievaluasi secara terbuka dengan prinsip dari, oleh, dan untuk masyarakat sehingga dapat dipertanggungjawabkan baik secara administratif, teknis, maupun hukum. 
Berdasarkan akan hal itu maka sudah sangat jelas bahwa pengelelolaan ADD harus dilaksanakan secara terbuka melalui musyawarah desa dan hasilnya dituangkan dalam Peraturan Desa (Perdes). Ketentuan tersebut menunjukkan adanya komitmen dari pengambil keputusan untuk memenuhi prinsip good governance dalam pengelolaan ADD. partisipasi masyarakat mwningkat seiring dengan komitmen yang kuat dari Pemerintah Kabupaten Brebes dan bebrarapa pihak terkait. Hal ini sesuai dengan informasi yang disampaikan informan bahwa:

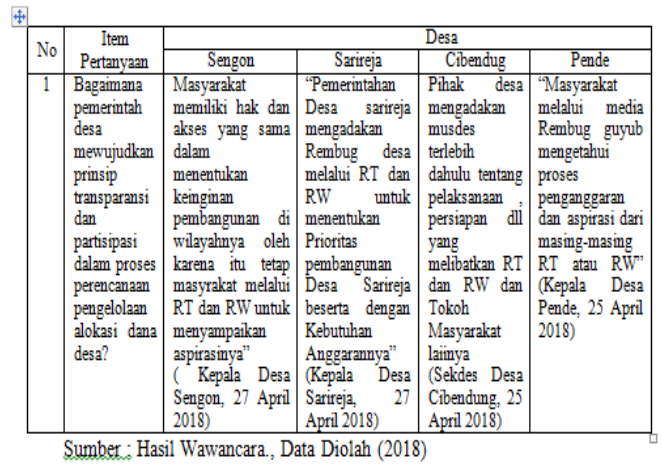

Transparansi dan partisipasi sangat penting bagi pelaksanaan fungsi-fungsi pemerintah dalam menjalankan mandat dari rakyat, mengingat pemerintah memiliki kewenangan mengambil berbagai keputusan penting yang berdampak bagi orang banyak, pemerinntah harus menyediakan informasi yang lengkap mengenai apa yang dikerjakannya.

Berdasarkan hasil tersebut pengelolaan Alokasi Dana Desa (ADD) di Kabupaten Brebes telah melaksanakan prinsip partisipatif yaitu dengan melibatkan unsur masyarakat didalam musyawarah penyusunan Rencana Kerja Pembangunan Desa (RKPDes), prinsip transparansi yaitu dibuktikan dengan masyarakat dapat melihat infromasi mengenai apa saja hasil dari musyawarah serta pembangunan yang akan dilaksanan oleh pemerintah desa, serta aspiratif yaitu dengan memberi kesempatan kepada masyarakat dalam mengajukan usulan-usulan pada forum musyawarah desa.

Pelaksanaan ini merupakan penerapan dari prinsip partisipatif pembangunan masyarakat desa yang didukung oleh prinsip-prinsip transparan, akuntabel, dan responsive.Implementasi prinsip-prinsip tersebut perlu diketahui secara jelas mulai dari tahap perencanaan, pelaksanaan, pertanggungjawaban dan pengawasan ADD secara lengkap. Hal ini sesuai dengan informasi yang disampaikan informan bahwa: 


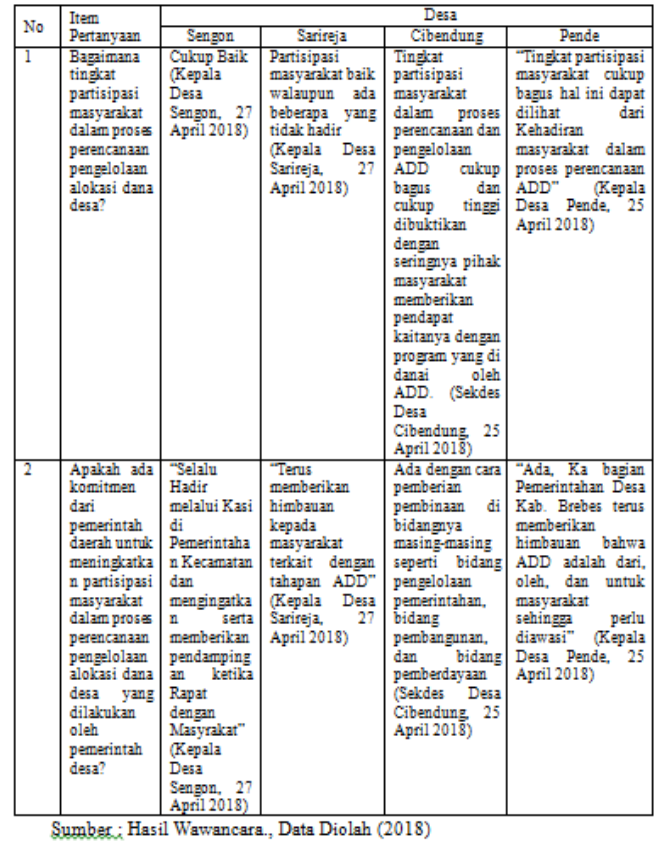

Berdasarkan hasil wawancara dengan beberapa informan dapat diperoleh informasi bahwa masyarakat di masing-masing desa Kabupaten Brebes secara partisipatif sejak dimulai proses penggalian gagasan di tingkat kelompok masyarakat baik yang formal maupun informal. Penggalian gagasan dari masing-masing kelompok masyarakat tersebut lebih menitik beratkan pada persoalan pembangunan desa secara luas dan menyeluruh baik dalam jangka pendek, menengah, maupun panjang yang memang menjadi kebutuhan masyrakat.Adapun penggalian gagasan tersebut dapat dilakukan melalui forum musyawarah Dusun (Mus Dus) dan Musyawarah- musyawarah laiinya. Setelah mendapatkan masukan/ gagasan maka Pemerintah Desa di Kabupaten Brebes terlebih dahulu menyusun Rencana Kerja Pemerintah Desa sebagai turunan dari Rencana Pembangunan Jangka Menengah Desa (RPJMD) yang telah disusun sebelumnya.

Keberhasilanpenyelesaian permasalahan di desa tentunya dari hasil kerja sama antara pemerintah desa dengan masyarakatnya. Dengan mengikuti musyawarah desa ini menunjukkan bahwa masyarakat ingin menyelesaikan permasalahan di desa masing-masing.Pelaksanaan ini merupakan penerapan dari prinsip partisipatif pembangunan masyarakat desa yang didukung oleh prinsipprinsip transparan, akuntabel, dan responsive.Implementasi prinsipprinsip tersebut perlu diketahui secara jelas mulai dari tahap perencanaan, pelaksanaan, pertanggungjawaban dan pengawasan ADD secara lengkap.

Pemerintah daerah melalui Camat mempunyai komitemen yang tinggi dalam meningkatkan partisipasi masyarakat dalam proses perencanaan pengelolaan alokasi dana desa hal ini 
terlihat dari hadirnya perwakilan dari kecamatan pada saat forum perencanaan seperti Rencana Kerja Pemerintah Desa (RKPDes) dan memberikan himbauan kepada masyarakat bahwa Alokasi Dana Desa atau Dana Desa adalah dari, oleh, dan untuk masyarakat sehingga perlu diawasi dan sebagi bentuk komitmen pemerintah Kecamatan melalui $\mathrm{Ka}$ Seksi Pemerintahan Desa melakukan pendampingan dan monitoring dengan berkala

\section{Perencanaan Alokasi Dana Desa}

Berdasarkan Musyawarah Perencanaan Pembangunan Desa (Musrenbangdes). Adapun Mekanisme perencanaan Alokasi Dana Desa (ADD) adalah sebagai berikut:

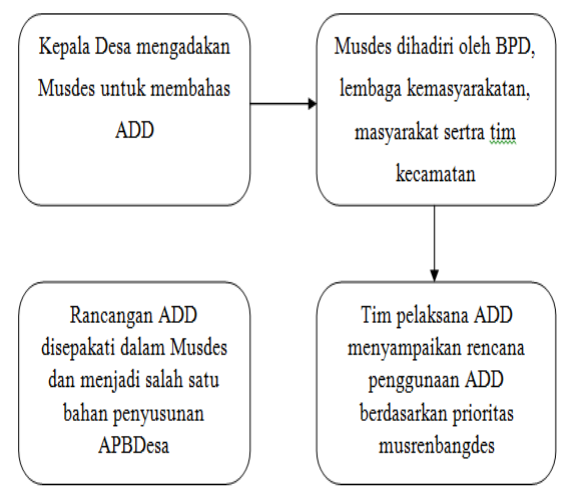

Gambar 1.1 Mekanisme Perencanaan Alokasi Dana Desa
Hasil wawancara dengan beberapa informan menyampaikan bahwa terkait dengan proses perencanaan adalah sebagai berikut:

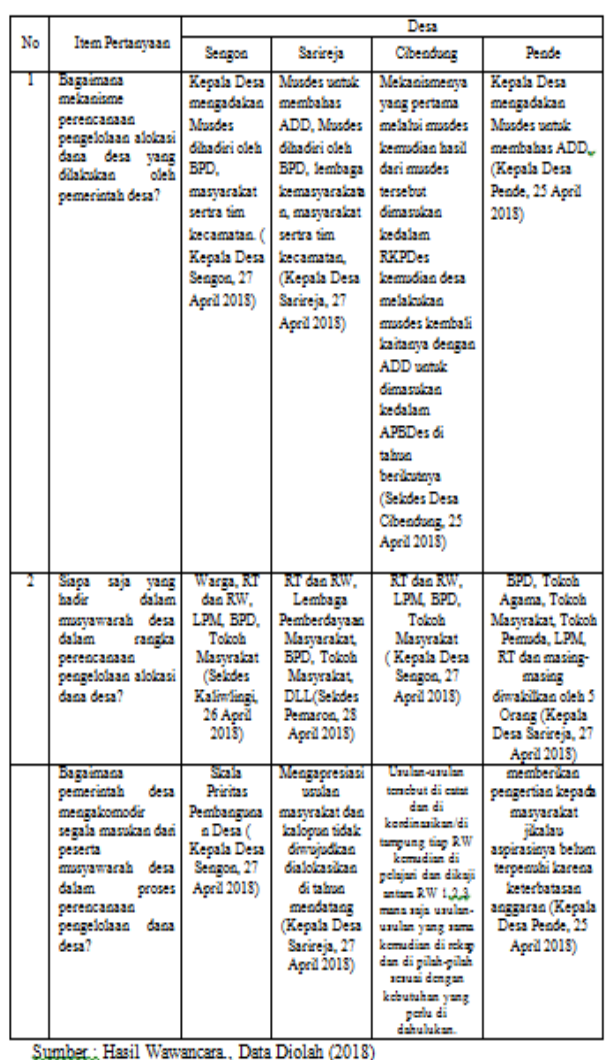

Berdasarkan hasil wawancara dengan beberapa informan, maka dapat disimpulkan bahwa Dalam tahap perencanaan pembangunan desa sudah sesuai dengan aturan yang berlaku yang mana pemerintah desa di kabupaten brebes sangat menjunjung tinggi transparansi terbukti dengan adanya suatu forum musyawarah desa yang di selenggarakan oleh Kepala Desa dan BPD yang dihadiri oleh Unsur masyarakat terdiri 
atas: tokoh adat, tokoh agama, tokoh masyarakat; tokoh pendidikan, perwakilan kelompok tani, nelayan dan lain-lain dalam rangka penyusunan rencana pembangunan Desa

\section{Pelaksanaan Alokasi Dana Desa}

A. Penyaluran Alokasi Dana Desa

Tahap pelaksanaan Alokasi Dana Desa disalurkan kepada masing-masing desa dengan cara pemindahbukuan dari Rekening Kas Umum Daerah ke Rekening Kas Desa. Rekening Kas Desa tersebut dibuat dengan menyertakan 3 (tiga) tanda tangan yang terdiri-dari Kepala Desa, Sekretaris Desa dan Bendahara Desa. Hal ini sesuai dengan hasil wawancara dengan beberapa informan menyampaikan bahwa terkait dengan proses pelaksanaan adalah sebagai berikut:

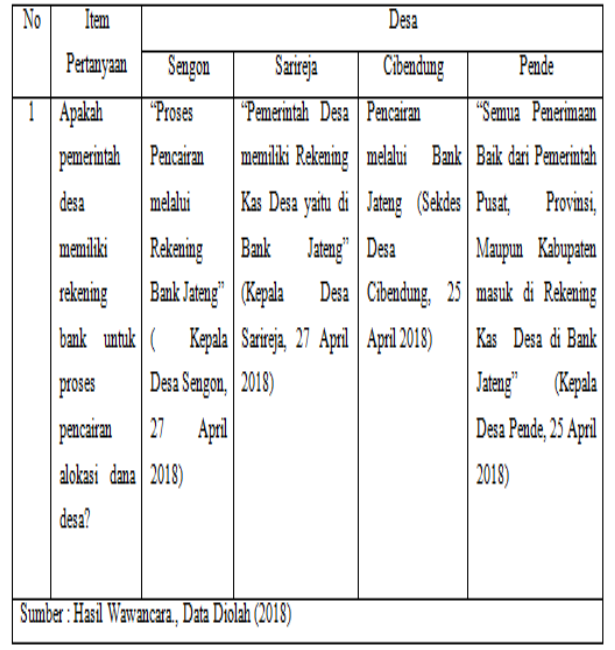

Adapun penyaluran ADD disalurkan dalam 2 tahap melalui rekening kas Desa dengan ketentuan sebagai berikut:

1. Tahap 1 (Pertama) sebesar $80 \%$ (delapan puluh persen) dari keseluruhan ADD yang akan diterima oleh setiap desa.

2. Tahap II (Kedua) sebesar 20\% (dua puluh persen) dari jumlah keseluruhan ADD yang merupakan sisa anggaran ADD setelah dikurangi Tahap 1 (pertama) yang belum disalurkan Kepala Desa.

Mekanisme Penyaluran

Mekanisme peyaluran Alokasi Dana Desa (ADD) dilaksanakan dengan cara Kepala Desa mengajukan berkas permohonan 
penyaluran ADD mengetahui Camat yang ditunjukan kepada Bupati Brebes cq. Kepala BPPKAD Kab Brebes melalui Kepala Bagian Pemerintahan Desa Setda Kab. Brebes yang dilampiri dengan persyaratan sesuai ketentuan.

\section{B. Mekanisme Pencairan Alokasi Dana Desa}

Setelah penyaluran dana Alokasi Dana Desa (ADD) disalurkan melalui masing-masing Desa melalui rekening Kas Desa. Selanjutnya Desa mengajukan proses pencairan ADD, dengan mekanisme kepala desa mengajukan Permohonan Pencairan Dana Kepada Camat dengan disertai persyaratan pencairan. Kepala Desa wajib melengkapi berkas pengajuan berupa Surat Permintaan Pembayaran (SPP) dan Rencana Anggaran Biaya (RAB).Setelah berkas diverivikasi dan dinyatakan lengkap dan benar Camat memberikan Surat Rekomendasi Pencairan Dana.

Tim Asistensi melakukan register/ pencatatan terhadap surat rekomendasi dan penerimaan berkas engajuan dari Desa serta menghimpun dan menyimpan arsip berkas pengajuan pencairan ADD guna keperluan audit oleh pengawas oleh pengawas fungsional

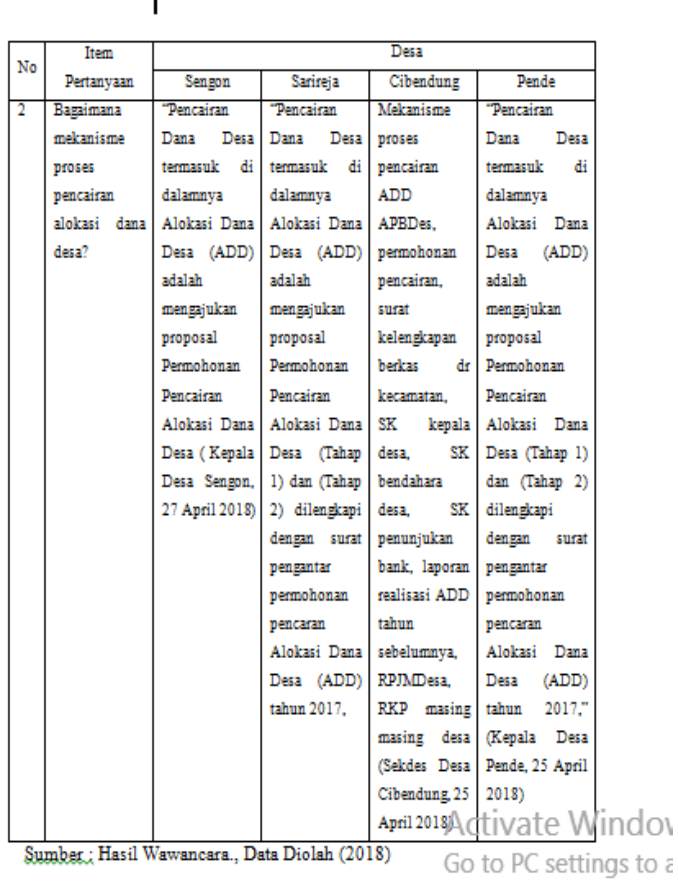

Peran pemerintah desa dalam mendukung keterbukaan dan penyampaian informasi secara jelas kepada masyarakat dalam proses pelaksanaan program yang di danai dari alokasi dana desa adalah melalui sosialiasi kepada masyarakat betapa pentingnya pengawasan terhadap Alokasi Dana Desa atau Dana Desa dan mengajak kepada masyarakat bahwa Dana Desa, Alokasi Dana Desa, dll adalah dari, oleh, dan untuk masyrakat sehingga masyarakat cukup andil dalam pembangunan desa.

Pelaksanaan kegiatan-kegiatan yang pembiayaannya bersumber dari ADD sepenuhnya dilaksanakan oleh Tim Pelaksanaan Desa. Dalam pelaksanaan program ADD ini, dibutuhkan keterbukaan 
dari Tim Pelaksana Desa kepada seluruh masyarakat. Salah satu bentuk transparansi pengunaan anggaran Dana Desa atau Alokasi Dana Desa pemerintah desa berinisiatif untuk mepublikasikan penggunaan Dana Desa melalui Banner dan Papan Informasi Kegiatan yang ditempatkan pada titik-titik tertentu yang strategis sehingga dapat dilihat masyarakat. Sehingga tidak menimbulkan perspektif yang negatif di masyrakat. Hal ini sesuai dengan yang disampaikan beberapa informaan bahwasannya:

\begin{tabular}{|c|c|c|c|c|c|}
\hline \multirow{2}{*}{ No } & hem & \multicolumn{4}{|c|}{ Den } \\
\hline & Destany $=$ & Sengan & Senteng & Chendung & Tende \\
\hline 3 & 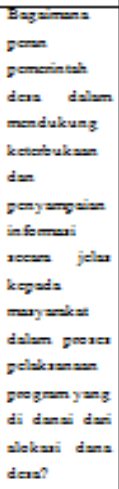 & 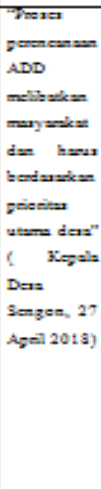 & 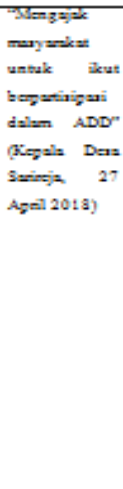 & 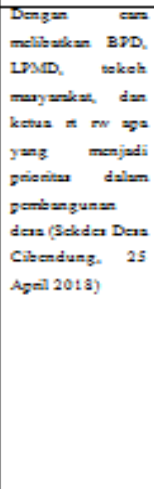 & 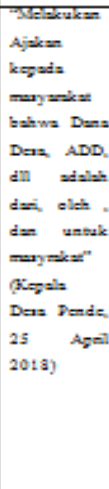 \\
\hline 4 & 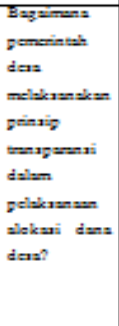 & 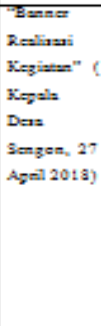 & 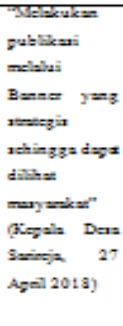 & 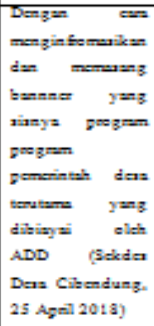 & 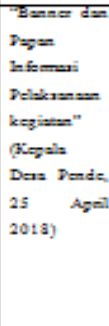 \\
\hline 3 & 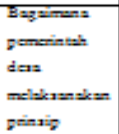 & 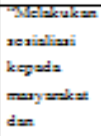 & 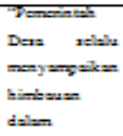 & 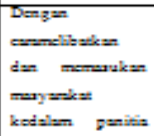 & 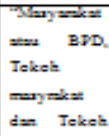 \\
\hline
\end{tabular}

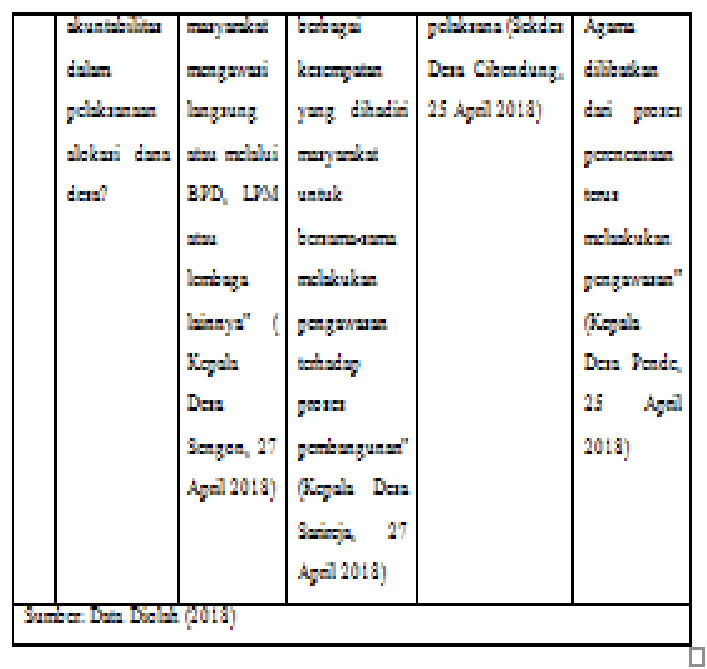

Berdasarkan hasil Musywarah Pembangunan Desa (Musrenbangdes) Pemerintah Desa Se-Kabupaten Brebes yang dihadiri oleh Kepala Desa, Perangkat Desa, BPD, LPM, BKM, PKK, RT dan RW Karang Taruna dan Tokoh Masyarakat Laiinya menitikberatkan pokok administratif (Non Fisik) dan Fisik guna Menunjang Pemerintahan Desa seperti: Bidang Penyelenggaraan Pemerintahan Desa, Bidang Pembinaan Kemasyarakatan, dan Bidang Pemberdayaan Masyarakat. Adapun untuk halhal yang termasuk dalam kegiatan administratif (Non Fisik) dapat dijelaskan pada tabel dibawah ini: 


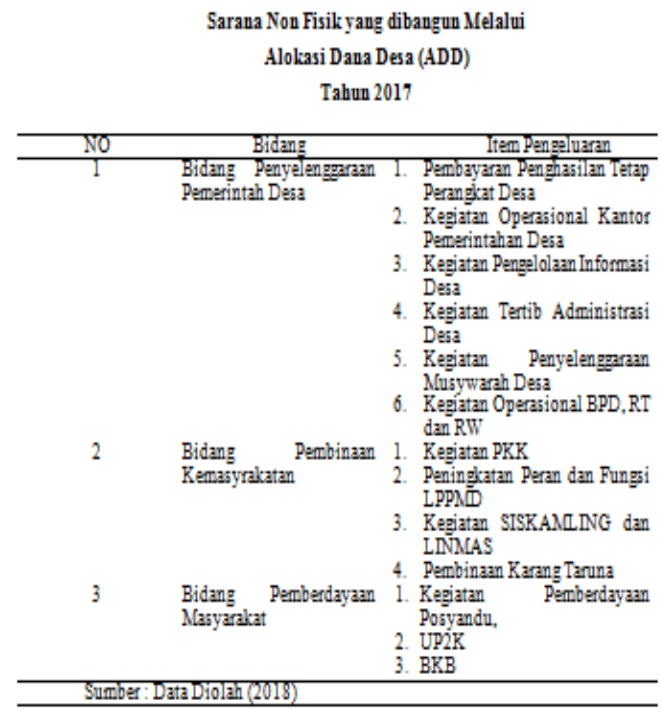

Tabel diatas menyajikan bahwa Bidang Penyelenggaraan Pemerintahan Desa, Bidang Pembinaan Kemasyarakatan, dan Bidang Pemberdayaan Masyarakat merupakan komponen penunjang guna kelancaran operasional desa. masing-masing Desa di Kabupaten Brebes mengalokasikan Dana Desa/ Alokasi Dana Desa

\section{Pertanggungjawaban Alokasi Dana Desa}

Pertanggungjawaban Pengelolaan ADD (Alokasi Dana Desa) di Kabupaten Brebes terintegrasi dengan pertanggungjawaban APBDes. Hal ini sesuai dengan Peraturan Menteri Dalam Negeri Nomor 113 Tahun 2014 tentang Pengelolaan Keuangan Desa ditandatangani oleh Menteri Dalam Negeri Tjahjo Kumolo pada tanggal 31 Desember
2014 ini sekaligus mencabut Peraturan Menteri Dalam Negeri Nomor 37 Tahun 2007 tentang Pedoman Pengelolaan Keuangan Desa. Peraturan tersebut dimaksudkan untuk memberikan landasan hukum bidang keuangan desa, sumber keuangan desa, dan anggaran pendapatan dan belanja desa.Penguatan keuangan desa dilakukan untuk menguatkan pilar transparansi dan akuntabilitas.

Pengelolaan keuangan desa harus dilakukan secara efisien dan efektif, transparan dan akuntabel. ADD yang merupakan salah satu sumber utama pendapatan desa juga harus dipertanggungjawabkan secara transparan kepada masyarakat maupun kepada pemerintah kabupaten sebagai institusi pemberi kewenangan. Selain itu, pertanggungjawaban kepada masyarakat dilakukan secara periodik setiap tiga bulan sekali melalui forum eveluasi pelaksanaan ADD yang dipimpin oleh Kepala Desa.Adapun Hasil wawancara lengkapnya dapat dilihat dalam tabel dibawah ini: 


\begin{tabular}{|c|c|c|c|c|c|}
\hline \multirow[t]{2}{*}{ No } & Item Pertanyan & \multicolumn{4}{|c|}{ Desa } \\
\hline & & Sengon & Sarieja & Cibendung & Pende \\
\hline \multirow[t]{10}{*}{1} & \multirow{10}{*}{ 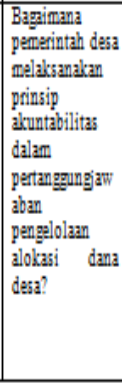 } & "Bisa diaktsers & "Dapat & dibuat infromasi & "Nelalui Banner \\
\hline & & masyarakat & dipertangyugga & berupas papan & Realisasi \\
\hline & & baik dalam & wabkan dan & dan bannes. & Pelaksanazn \\
\hline & & Banner atall & dilaporkan pada & (Sakdes Deja & Kegajtan \\
\hline & & $\begin{array}{l}\text { proses } \\
\text { nelakumann }\end{array}$ & 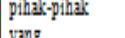 & 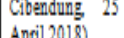 & masyaralat bisa \\
\hline & & ADD" (Kepala & berwenzag" & & penilaian dan \\
\hline & & Desa Sengon, & (Keppla Desa & & Pelalszanazan \\
\hline & & 27 April 2018) & Sarisgia, 27 & & ADD dapat \\
\hline & & & Aptil 2018) & & $\begin{array}{l}\text { dipertangengiga } \\
\text { wabkan" }\end{array}$ \\
\hline & & & & & $\begin{array}{l}\text { (Repala Desa } \\
\text { Pende, } 25 \text { April } \\
\text { 2018) }\end{array}$ \\
\hline & & & & & \\
\hline
\end{tabular}

\section{Pelaporan ADD berupa:}

\section{a. Laporan Berkala}

Laporan berupa rekapitulasi realisasi keuangan dan realisasi fisik pelaksanaan ADD dilengkapi dengan himpunan Laporan Realisasi Pelaksanaan APBDesa per semester, yang dialporkan secara berkala per semester oleh Camat Kepada Bupati Brebes cq. Kepala Bagian Pemerintahan Desa Setda Brebes

\section{b. Laporan Akhir}

Kepala Desa menyampaian laporan realisasi pelaksanaan APBDesa ke Bupati/ Walikota melalui Camat berupa laporan Semeseter 1 dan Semester II. Adapun mekanisme pertanggungjawaban keuangan Desa adalah sebagai berikut: 1 . Kepala Desa menyampaikan laporan pertanggungjawaban realisasi pelaksanaan APBDesa Kepada Bupati/ Walikota melalui Camat. 2. Laporan
Pertanggungjawaban realisasi pelaksanaan APBDesa dilampiri: Laporan Pertanggungjawaban Realisasi pelaksanaan APBDesa dan Laporan Kekayaan Milik Desa per 31 Desember. Adapun batas waktu untuk laporan Realisasi Pelaksanaan APBDesa adalag Semester I paling lambat akhir bulan juli tahun berjalan dan Semester II paling lambat akhir bulan januari tahun berikutnya sedangkan untuk laporan pertanggungjawaban realisasi pelaksanaan APBDesa disampaikan maksimal 1 (satu) bulan setelah akhir tahun anggaran berkenaan. Sebagai bentuk transparansi dan akuntabilitas kepada masyarakat laporan realisasi dan laporan pertanggungjawaban realisasi pelaksanaan APBDesa diinformasikan kepada masyarakat ecara tertulis dan dengan media informasi yang mudah diakses masyarakat. Penyampaian laporan dilaksanakan melalui jalur struktural yaitu dari Tim Pelaksana Tingkat Desa dan diketahui Kepala Desa ke Tim Pendamping Tingkat Kecamatan secara bertahap

Informasi-informasi dibawah ini menunjukkan bahwa sistem pertanggungjawaban pelaksanaan ADD di 
Kabupaten Brebes telah melaksanakan prinsip akuntabilitas. Dan pengelolaan ADD juga telah melaksanakan pertanggungjawaban administrasi keuangan ADD dengan baik yaitu setiap pembelanjaan yang bersumber dari ADD harus disertai dengan bukti.Evaluasi pelaksanaan program ADD tersebut juga membimbing masyarakat untuk berpartisipasi aktif dalam memberikan masukan dan koreksi dengan adanya kerja sama saling membantu antara perangkat desa, bendahara desa, tim pelaksanaan Alokasi Dana Desa agar pelaporan ADD dapat diselesaikan dengan cepat dan tepat. Dapat diketahui bahwa pelaksanaan ADD sudah memahami dan mengerti tentang tata kelola administrasi keuangan ADD karena selalu ada petunjuk dari pemerintah Kabupaten

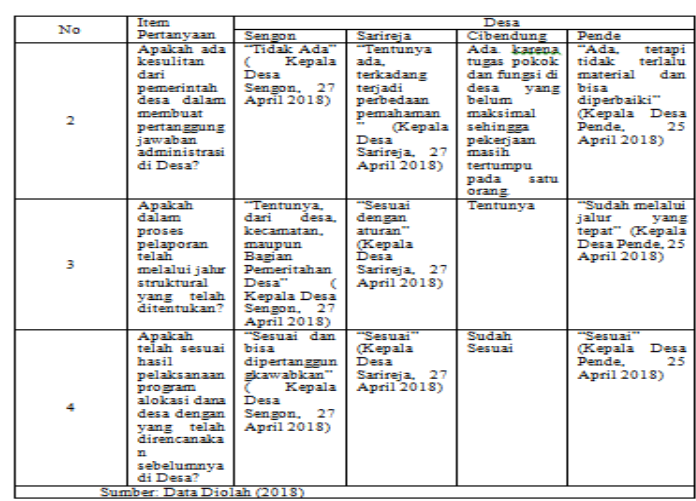

\section{Pengawasan Alokasi Dana Desa}

\begin{tabular}{|c|c|c|c|c|c|}
\hline \multirow[b]{2}{*}{ No } & \multirow{2}{*}{$\begin{array}{c}\text { Item } \\
\text { Pertanyaan }\end{array}$} & \multicolumn{4}{|c|}{ Desa } \\
\hline & & Sengon & Sariseja & Cibendung & Pende \\
\hline & $\begin{array}{l}\text { Baggimana } \\
\text { bentuk } \\
\text { pengawasa } \\
\text { n yang } \\
\text { dilakukan } \\
\text { oleh } \\
\text { pemerintah } \\
\text { kecamatan } \\
\text { kepada } \\
\text { desa dalam } \\
\text { rangka } \\
\text { pengelolas } \\
\text { n alokasi } \\
\text { dana desa? }\end{array}$ & $\begin{array}{l}\text { Masyrakat, } \\
\text { pendamping, } \\
\text { danu unsur } \\
\text { kelenglapan } \\
\text { negara ikut } \\
\text { mengawasi } \\
\text { pelaksanaan } \\
\text { ADD tidak } \\
\text { hanya oleh } \\
\text { kecamatan" ( } \\
\text { Kepala Desa } \\
\text { Sengon. 27 } \\
\text { April 2018) }\end{array}$ & $\begin{array}{l}\text { "pemerintah } \\
\text { kecamatan dan } \\
\text { Bagian } \\
\text { Pemerintahan } \\
\text { desa (SETDA } \\
\text { BREBES) ikut } \\
\text { mengawasi dan } \\
\text { selalu } \\
\text { monitoring" } \\
\text { (Kepala Desa } \\
\text { Sarireja, 27 } \\
\text { April 2018) }\end{array}$ & $\begin{array}{l}\text { Bentul: } \\
\text { pengawasan } \\
\text { yang } \\
\text { dilakukan } \\
\text { oleh } \\
\text { pemerintah } \\
\text { kecamatan } \\
\text { adalah } \\
\text { monitoring } \\
\text { oleh kasi } \\
\text { pMD } \\
\text { kemudian di } \\
\text { bentuk tim } 1 \\
\text { dan tim } 2 \text {. } \\
\text { Tim } 1 \text { yang } \\
\text { beranggotaka } \\
\text { n camat, kasi } \\
\text { dan staf tim } 2 \\
\text { beranggotkan } \\
\text { sekcamkasi } \\
\text { dan staf. }\end{array}$ & $\begin{array}{l}\text { Berbagai } \\
\text { Stakeholder } \\
\text { tidak hanya } \\
\text { pemerintah } \\
\text { kecamatan } \\
\text { bahkan } \\
\text { inspektorat jus } \\
\text { melakukan } \\
\text { kegiatan } \\
\text { pengawasan" } \\
\text { (Kepala Desa } \\
\text { Pende, } 25 \text { Apri } \\
\text { 2018) }\end{array}$ \\
\hline
\end{tabular}

Pemantauan dan Evaluasi atas penyaluran dan penggunaan serta realisasi ADD dilaksanakan oleh tim fasilitasi maupun bagian pemerintahan desa Kab Brebes

\section{SIMPULAN}

Akuntabilitas Alokasi Dana Desa di Kabupaten Brebes dapat di ambil kesimpulan sebagai berikut :

1. Perencanaan Alokasi Dana Desa (ADD) di Kabupaten Brebes sudah melaksanakan pembangunan partisipatif yang terlihat dari pembangunan yang mengacu pada skala prioritas, kondisi, situasi masyarakatnya.

2. Pelaksanaan Alokasi Dana Desa (ADD) di Kabupaten Brebes Proses pencairan Alokasi Dana Desa Pada Tahun 2017 
Adalah dibagi menjadi 2 Tahap. Tahap pertama (pertama) sebesar 80\% dan Tahap 2 (Kedua) sebesar 20\%. Penyaluran Anggaran Dana Desa yang didalamnya termasuk Alokasi Dana Desa (ADD) disalurkan dari rekening Kas Umum Negara ke Rekening Kas Umum Daerah

3. Pertanggungjawaban Alokasi Dana Desa (ADD) Pertanggungjawaban Pengelolaan ADD (Alokasi Dana Desa) di Kabupaten Brebes terintegrasi dengan pertanggungjawaban APBDes.

4. Pengawasan Alokasi Dana Desa (ADD) dilakukan oleh pemerintah kecamatan kepada desa dalam rangka pengelolaan alokasi dana desa secara berjenjang dari level pusat hingga ke-daerah.

\section{REFERENSI}

Arifiyanto, D. F. (2014). Akuntabilitas Pengelolaan Alokasi Dana Desa di Kabupaten Jember. Riset Akuntansi dan Keuangan.

Dinas Komunikasi Informatika dan Statistik Kabupaten Brebes . (2017) Brebes Dalam Data 2016

Kementrian Keuangan Republik Indonesia. (2017) Buku Pintar Dana Desa
Kholmi, M. (2016). Akuntabilitas Pengelolaan Alokasi Dana Desa : Studi di Desa Kedungbetik Kecamatan Kesamben Kabupaten Jombang. EkonomikaBisnis, 143-152.

Mardiasmo. (2009). Akuntansi Sektor Publik. Yogyakarta: ANDI.

Muslimin, M. N. (2012). Akuntabilitas Pengeloaan Alokasi Dana Desa di Desa Punagaya Keamatan Bangkala Kabupaten Jeneponto. Otoritas, 79-85.

Peraturan Daerah Kabupaten Brebes Nomor 4 Tahun 2015 tentang Keuangan Desa

Peraturan Bupati Nomor 100 Tahun 2016 tentang Alokasi Dana Desa Kabupaten Brebes

Undang-Undang N0 32 Tahun 2004 Tentang Pemerintahan Daerah 